\title{
EVALUATION OF DENGUE NS1 ANTIGEN DETECTION FOR DIAGNOSIS IN PUBLIC HEALTH LABORATORIES, SÃO PAULO STATE, 2009
}

Ivani BISORDI(1), Iray Maria ROCCO(1), Akemi SUZUKI(1), Gizelda KATZ(1), Vivian Regina SILVEIRA(1), Adriana Yurika MAEDA(1), Renato Pereira de SOUZA(1), Margarida Georgina BASSI(2), Eloisa Fonseca DEL TEDESCO(3), Eithma FREITAS(4), Thirsa Álvares Franco BESSA(5) \& DENGUE-NS1 GROUP(1-6)

\begin{abstract}
SUMMARY
The present work evaluated the diagnostic accuracy of detection of Dengue NS1 antigen employing two NS1 assays, an immunochromatographic assay and ELISA, in the diagnostic routine of Public Health laboratories. The results obtained with NS1 assay were compared with virus isolation and, in a subpopulation of cases, they were compared with the IgM-ELISA results obtained with convalescent samples. A total of 2,321 sera samples were analyzed by one of two NS1 techniques from March to October 2009. The samples were divided into five groups: groups I, II and III included samples tested by NS1 and virus isolation, and groups IV and V included patients with a first sample tested by NS1 and a second sample tested by IgM-ELISA. Sensitivity, specificity, positive and negative predictive values, Kappa Index and Kappa Concordance were calculated. The results showed that NS1 testing in groups I, II and III had high sensitivity (98.0\%, 99.5\% and 99.3\%), and predictive values and Kappa index between 0.9 - 1.0. Groups IV and V only had Kappa Concordance calculated, since the samples were analyzed according to the presence of NS1 antigen or IgM antibody. Concordance of $92.1 \%$ was observed when comparing the results of NS1-negative samples with IgM-ELISA. Based on the findings, it is possible to suggest that the tests for NS1 detection may be important tools for monitoring the introduction and spread of Dengue serotypes.
\end{abstract}

KEYWORDS: Dengue; Diagnosis; NS1 ELISA; NS1 immunochromatographic.

\section{INTRODUCTION}

The Dengue virus (DENV-1, DENV-2, DENV-3 and DENV-4) belongs to the Flavivirus genus of the Flaviviridae family. The genomic RNA is a single strand with approximately $11 \mathrm{~kb}$ in length and is composed of three structural protein genes that encode the nucleocapsid or core proteins $(\mathrm{C})$, a membrane-associated protein $(\mathrm{M})$, an envelope protein (E) and seven nonstructural protein genes: NS1, NS2a, NS2b, NS3, NS4a, NS4b and NS5 ${ }^{4}$.

Dengue fever has been clinically described in Brazil since the $19^{\text {th }}$ century $^{8}$, but laboratorial diagnosis was only introduced in 1981 in Boa Vista city, Roraima State in the Amazon region, when the serotypes 1 and 4 were isolated ${ }^{23}$.

After 1981, only a few cases were reported, until 1986, when an outbreak caused by DENV-1 was confirmed in Rio de Janeiro, spreading to the other urban centers ${ }^{18}$. DENV-2 was introduced in 1990 and DENV-
3, in $2002^{21,22}$. In 2010, the re-introduction of DENV-4 in Roraima State was confirmed. It subsequently spread to other states in the North ${ }^{19}$ (states of Amazonas and Pará) and in the Northeast (states of Bahia, Pernambuco and Piauí) $)^{20}$.

In the Southeast, the first episode of the disease occurred in the Rio de Janeiro State in $2011^{20}$. In the São Paulo State, the isolation of DENV-4 was confirmed in February 2011 in patients residing in São José do Rio Preto and Paulo de Faria, two counties located in the northwestern region of the State (Rocco I.M., unpublished data).

Diagnostic methods currently available for the dengue virus infections are IgM antibody capture enzyme-linked immunosorbent assay (MACELISA), virus isolation in Aedes albopictus (C6/36) mosquito cells, and nested reverse transcription-polymerase chain reaction (Nested RT-PCR).

MAC-ELISA is the test of choice for rapid diagnosis in a single sample, collected after the $5^{\text {th }}$ day of disease ${ }^{28}$. Serotype identification is obtained

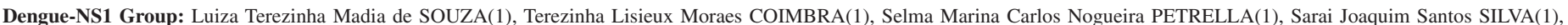

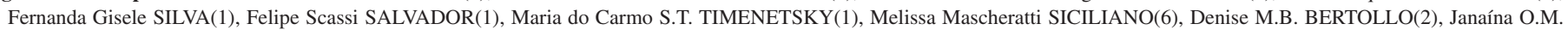
MONTANHA(2), Rodrigo F. POVINELI(2), Jandira O.F. da SILVA(3), Madalena H.T. OKINO(3), Suely M. GERACE(3).

(1) Instituto Adolfo Lutz, São Paulo, SP, Brazil.

(2) Centro de Laboratórios Regionais (CLR) do Instituto Adolfo Lutz de São José do Rio Preto, SP, Brazil.

(3) CLR do Instituto Adolfo Lutz de Ribeirão Preto, SP, Brazil.

(4) CLR do Instituto Adolfo Lutz de Presidente Prudente, SP, Brazil

(5) Laboratório de Zoonoses e Doenças Transmitidas por Vetores do Centro de Controle de Zoonoses (CCZ) do Município de São Paulo, SP, Brazil.

(6) Centro de Vigilância Epidemiológica "Prof. Alexandre Vranjac", São Paulo, SP, Brazil.

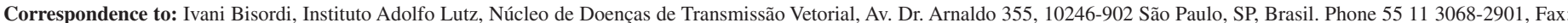
5511 3086-3505. E-mail: ibisordi@yahoo.com.br 


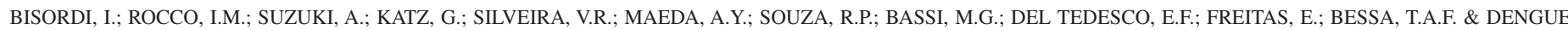
NS-1 GROUP - Evaluation of dengue NS1 antigen detection for diagnosis in public health laboratories, São Paulo State, 2009. Rev. Inst. Med. Trop. São Paulo 53(6): 315-20, 2011.

after virus isolation in cell culture by indirect immunofluorescence assay (IFA) using type-specific monoclonal antibodies ${ }^{10}$.

The detection of the viral genome by RT-PCR, with specific primers for each serotype in clinical samples of the acute-phase of infection, can be performed by different protocols ${ }^{2,5,13}$. However, both virus isolation and RT-PCR procedures require sophisticated laboratories, skillful technicians, adherence to strict biosafety standards and good laboratory practices.

Recently, tests for detecting the Dengue NS1 antigen in human serum have been evaluated ${ }^{1,6,27,29}$. The NS1 antigen is found together with endothelium, free or soluble in the sera of patients, from one day before the onset of symptoms and can be detected at least up to five days after the onset of symptoms, allowing for an early diagnosis ${ }^{1,6,12,27,29}$. A previous study concluded that the test was more sensitive with samples collected up to day 3 after the onset of symptoms ${ }^{6}$.

There are two NS1 assay formats: immunochromatographic and ELISA. The immunochromatographic has the advantage of being faster and not requiring a sophisticated laboratory with expensive equipment ${ }^{6}$, while the ELISA assay takes longer and requires a better-equipped laboratory.

The present work aimed to evaluate the diagnostic accuracy for the detection of the Dengue NS1 antigen by two different assay formats: immunochromatographic and ELISA, when employed by Public Health laboratories. The results obtained with NS1 assays were compared with those obtained by the virus isolation technique, and also with those obtained in the second samples processed by IgM-ELISA.

\section{MATERIALS AND METHODS}

Sample collection: Serum samples were collected from March to October 2009 and sent for virus isolation at the Núcleo de Doenças de Transmissão Vetorial (NDTV) at the Instituto Adolfo Lutz, SP (IAL). These samples had been previously analyzed by NS1 assay at the Centro de Laboratórios Regionais (CLR) de São José do Rio Preto, in the counties of Ribeirão Preto and Presidente Prudente as well as at the Laboratório de Zoonoses e Doenças Transmitidas por Vetores from the Centro de Controle de Zoonoses of São Paulo (the capital city) (CCZ).

Serum samples collected up to the $3^{\text {rd }}$ day after the onset of symptoms from patients clinically suspected of dengue infection, according to the definition of suspected $\operatorname{cases}^{28}$, were selected. The samples were collected in the acute phase of infection (days 1 to 3 after the onset of the symptoms). Day zero was considered the day of the onset of fever. Technicians from all network laboratories of $I A L$ were trained to select samples and conduct tests for NS1 detection in both formats. Serum samples taken after the $3^{\text {rd }}$ day and samples taken from dengue-suspected fatal cases were excluded.

The samples were processed as follows: 1) NS1-positive and NS1 negative samples were submitted to virus isolation; 2) patients whose serum samples were NS1-negative were requested to have a $2^{\text {nd }}$ blood sample collected from the $6^{\text {th }}$ day after the onset of symptoms for IgMELISA assay using commercial kits.
Evaluation of the technique of NS1 was made during the routine use of diagnostic kits, some samples were only processed by NS1 and these results were not confirmed by virus isolation or by IgM capture ELISA.

Although no specific protocol was established for this study, we analyzed the content of databases in order to obtain a broad and representative sample from the diagnostic routine of Public Health laboratories.

The test results analyzed in this study were obtained from the Information System and Hospital Management (SIGH). This database was implemented by, and is broadly used in the Instituto Adolfo Lutz's laboratory network.

According to data extracted from SIGH and with the aim of conducting a performance analysis, samples were classified into five groups:

Group I: comprised 1,055 acute samples processed by NS1, with no information about which kit was used for NS1 detection (Immunochromatographic or ELISA) and using virus isolation as a reference technique.

Group II: comprised 266 acute samples, processed by NS1immunochromatographic and using virus isolation as a reference technique.

Group III: comprised 362 acute samples, processed by NS1-ELISA and using virus isolation as a reference technique.

Group IV: comprised 747 acute samples processed by NS1immunochromatographic and by IgM-ELISA commercial kits, performed on their respective convalescent samples.

Group V: comprised 519 samples processed by NS1-ELISA and by IgM-ELISA commercial kits, performed on their respective convalescent samples.

Detection of NS1 protein: we used the ELISA tests Platelia ${ }^{\mathrm{TM}}$ Dengue NS1 Ag. Kit (Bio-Rad Laboratories, Marnes La Coquette, France) and Dengue Early ELISA PanBio (Inverness Medical Innovations Australia Pty Ltd /IMIA). The immunochromatographic assay used was the Dengue NS1 Ag. STRIP Kit (Bio-Rad Laboratories, Marnes La Coquette, France). The tests were performed according to manufacturer's instructions.

IgM-ELISA commercial kit: Dengue IgM Capture ELISA Kit (Panbio Limited, Brisbane, Australia) was employed to analyze the convalescent samples, when the acute samples were NS1 non-reactive. The tests were performed following the manufacturer's instructions.

Virus isolation: The viruses were isolated in tissue cultures. Twenty microliters of each serum sample were inoculated into tubes containing Aedes albopictus (C6/36) mosquito cells and incubated for nine days at $28{ }^{\circ} \mathrm{C}$ in L-15 Leibovitz medium. After this period, the infection was detected by indirect immunofluorescence assays (IFA) ${ }^{10}$, using a pool of mice-immune ascitic fluid against the four Dengue serotypes ${ }^{3}$. The serotypes were identified by IFA using monoclonal antibodies ${ }^{10}$. 


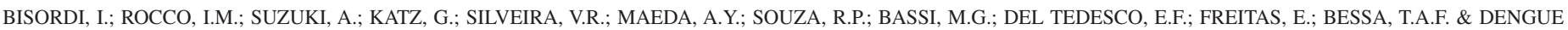
NS-1 GROUP - Evaluation of dengue NS1 antigen detection for diagnosis in public health laboratories, São Paulo State, 2009. Rev. Inst. Med. Trop. São Paulo 53(6): 315-20, 2011.

NS1 tests were analyzed for sensitivity; specificity; positive predictive value (PPV); negative predictive value (NPV), with a 95\% confidence interval $(\mathrm{CI})$ for Groups I, II and III; probability $(P)$ value between Groups II and III ${ }^{9,11,15}$; Kappa Index; and Concordance ${ }^{14}$. The samples with negative results in NS1 tests and virus isolation were used to analyze specificity.

For groups IV and V, only Kappa Concordance was calculated. Sensitivity, specificity, positive and negative predictive values were not calculated, since samples were different (acute or first and convalescent or second) and aimed at different diagnostic purposes (antigens or antibodies).

Ethical considerations: there were no conflicts of interest between the suppliers and producers of the kits and the Public Health Laboratories. We have analyzed only information retrieved from laboratory databases. All the samples included in the study were received by the laboratory for dengue diagnosis. The identities of the patients were kept confidential and biological samples were identified only by numbers.

\section{RESULTS}

A total of 2,321 samples were analyzed by one of two NS1 techniques, and their results were compared to those obtained by virus isolation and IgM-ELISA.

Considering the 1,055 samples classified in Group I, which were analyzed by the NS1 test and using virus isolation as a reference, with no information in SIGH about which kit was used for NS1 detection, 790 were NS1-positive and 726 of these were positive for virus isolation. The concordance between these two methodologies was $91.9 \%$. Among the 265 NS1-negative samples, there were 13 (4.9\% of false NS1-negative) positive virus isolations (Table 1).

Among the 266 samples processed by NS1-immunochromatographic
Table 1

Results of NS1- immuochromatographic and NS1-ELISA compared to virus isolation (Group I)

\begin{tabular}{lccc}
\hline \multirow{2}{*}{ NS1* } & \multicolumn{3}{c}{ Virus isolation } \\
\cline { 2 - 4 } & Positive (\%) & Negative $(\%)$ & Total $(\%)$ \\
\hline Positive & $726(98.2)$ & $64(20.3)$ & $790(74.9)$ \\
Negative & $13(1.8)$ & $252(79.7)$ & $265(25.1)$ \\
\hline Total & $739(100.0)$ & $316(100.0)$ & $1055(100.0)$ \\
\hline
\end{tabular}

* NS1: ELISA and immuochromatographic tests.

(Group II), 225 were NS1-positive. Out of a total of 362 samples processed by NS1-ELISA (Group III), 291 were NS1-positive. A concordance of $95.5 \%$ (Table 2) was observed when comparing the results obtained in the Groups II and III with the results of virus isolation.

Both formats of NS1 tests (ELISA and immunochromatographic) presented high sensitivity: 98.0\% (95\% CI: 97.2\% - 99.1\%) for Group I, $99.5 \%$ (95\% CI: $98.6 \%$ - 100.0\%) for Group II and $99.3 \%$ (95\% CI: $98.3 \%-100.0 \%$ ) for Group III. PPV and NPV were equally high. The differences in performance between groups II and III were not statistically significant $(p>0.05)$. The Kappa Index (Table 3$)$ was evaluated as excellent $(0.9-1.0)^{14}$.

The study protocol required that NS1-negative patients should return after the sixth day to collect a convalescent sample. Out of the 1,439 NS1-negative patients only $1,174(81.6 \%)$ returned. A concordance of $92.1 \%$ was observed, comparing the results obtained with NS1-negative (immunochromatographic and ELISA) and the results obtained with IgM-ELISA.

Additionally, tests performed on the second blood samples collected

Table 2

Results of NS1 immunochromatographic test (Group II) and NS1 ELISA test (Group III) compared to virus isolation

\begin{tabular}{lccccccc}
\hline \multicolumn{7}{c}{ Virus isolation } \\
\hline NS1 Group II & Positive (\%) & Negative $(\%)$ & Total & NS1 Group III & Positive (\%) & Negative (\%) & Total \\
\hline Positive & $215(99.5)$ & $10(20.0)$ & $225(84.6)$ & Positive & $278(99.3)$ & $13(15.9)$ & $291(80.4)$ \\
Negative & $1(0.5)$ & $40(80.0)$ & $41(15.4)$ & Negative & $2(0.7)$ & $69(84.1)$ & $71(19.6)$ \\
\hline Total & $216(100)$ & $50(100)$ & $266(100)$ & Total & $280(100)$ & $82(100)$ & $362(100)$ \\
\hline
\end{tabular}

Table 3

Sensitivity, specificity, predictive values, confidence interval and Kappa index of Groups I, II and III

\begin{tabular}{lcccc}
\hline Groups & $\begin{array}{c}\text { Sensitivity } \\
(\%), 95 \% \text { CI* }\end{array}$ & $\begin{array}{c}\text { Specificity } \\
(\%), 95 \% \text { CI }\end{array}$ & $\begin{array}{c}\text { PPV* } \\
(\%), 95 \% \text { CI }\end{array}$ & $\begin{array}{c}\text { NPV* } \\
(\%), 95 \% \text { CI }\end{array}$ \\
\hline I & $98.0,97.2-99.1$ & $80.0,75.3-84.1$ & $92.0,90.0-93.8$ & $95.0,92.4-100.0$ \\
II & $99.5,98.6-100.0$ & $80.0,68.9-91.1$ & $95.6,92.9-98.2$ & $97.6,92.8-100.0$ \\
III & $99.3,98.3-100.0$ & $84.1,76.2-92.0$ & $95.5,93.2-97.9$ & $97.2,93.3-100.0$ \\
\hline
\end{tabular}

* 95\% confidence interval; Positive Predictive Value (PPV); Negative Predictive Value (NPV) 
BISORDI, I.; ROCCO, I.M.; SUZUKI, A.; KATZ, G.; SILVEIRA, V.R.; MAEDA, A.Y.; SOUZA, R.P.; BASSI, M.G.; DEL TEDESCO, E.F.; FREITAS, E.; BESSA, T.A.F. \& DENGUE NS-1 GROUP - Evaluation of dengue NS1 antigen detection for diagnosis in public health laboratories, São Paulo State, 2009. Rev. Inst. Med. Trop. São Paulo 53(6): 315-20, 2011.

Table 4

Dengue virus serotypes isolated from NS1 samples

\begin{tabular}{|c|c|c|c|c|}
\hline Virus & $\begin{array}{c}\text { DENV-1 } \\
\left.\text { No. }^{\circ} \%\right)\end{array}$ & $\begin{array}{c}\text { DENV-2 } \\
N^{\circ} .(\%)\end{array}$ & $\begin{array}{l}\text { DENV-3 } \\
N^{\circ} .(\%)\end{array}$ & $\begin{array}{c}\text { Total } \\
\mathrm{N}^{\mathrm{o}} .(\%)\end{array}$ \\
\hline NS1 - Positive & $533(99.1)$ & $22(78.6)$ & $171(98.8)$ & $726(98.2)$ \\
\hline NS1 - Negative & $5(0.9)$ & $6(21.4)$ & $2(1.2)$ & $13(1.8)$ \\
\hline Total & $538(100.0)$ & $28(100.0)$ & $173(100.0)$ & $739(100.0)$ \\
\hline
\end{tabular}

from 92 NS1-positive patients showed $98.9 \%$ agreement between NS1 and IgM tests.

The most frequently isolated serotype observed was DENV-1 (538), followed by DENV-3 (173) and DENV-2 (28), with NS1 sensitivities of $99.1 \%, 98.8 \%$ and $78.6 \%$ respectively (Table IV).

Concerning the analysis of DENV serotypes, it is important to point out that, NS1-positive samples from Groups II and III (516), are included in the total number of Group I samples. Only 516 out of 739 samples had information on which type of NS1 test was used.

\section{DISCUSSION}

Reported cases of dengue infection with hemorrhagic manifestations and other complications have become increasingly more frequent in tropical areas ${ }^{17}$.

Over the last few years, a shift in the age distribution of patients has been observed. Previously, dengue hemorrhagic fever (DHF) cases occurred mainly in adults, but currently there is a predominance of children under 15 years of age, especially in the northeastern region of Brazil where $65 \%$ of the total number of DHF cases were detected ${ }^{25}$. Furthermore, healthcare authorities should be prepared for the spread of DENV-4 since its re-introduction into Brazil in $2010^{26}$.

There is an urgent need for a rapid, simple and sensitive laboratory assay, which would permit early clinical management of patients, preventing the malignant evolution of the disease, and would also allow for the rapid notification of public health authorities.

The NS1 tests can be used in hospitals as an important instrument to aid adequate support during a patient's admission ${ }^{7}$, and the NS1 immunochromatographic assay has also been shown to be efficient in airports for the detection of imported cases ${ }^{27}$.

The NS1 assay was used routinely by the public health laboratories of the São Paulo State from March to October 2009, and for the results analysis, the kit trademarks were not taken into consideration, only the format of the kits (ELISA or immunochromatographic).

It is possible that the results obtained using the testing strategy outlined in this study will be different from results obtained from established dengue serum panels used to test new assays, due to the poorer quality of samples, such as lipemic or hemolyzed sera, with rheumatoid factor or unsuitable transport, storage and handling, all of which can affect assay results ${ }^{15}$.

The NS1 tests were performed at different laboratories and the samples were not analyzed for the presence of interfering factors such as lipids, rheumatoid factor and hemolysis. Consequently, the implication of these possible interfering factors could not be measured in this study.

Despite the different testing locations and conditions in this study, the results with samples collected up to the $3^{\text {rd }}$ day indicate high sensitivity, specificity, PPV and NPV in NS1 immunochromatographic and NS1 ELISA assays, when compared with virus isolation (Table 3).

The samples selected to analyze specificity were the ones that resulted negative in NS1 and virus isolation. Perhaps, due to this different purpose, the results for specificity were lower, in contrast with other studies ${ }^{6,16,24}$ (Table 3). For Groups IV and V, only concordance was calculated. These groups comprised samples processed for IgM-ELISA, and these samples were not included to calculate specificity.

Comparing the results obtained by virus isolation and NS1 tests, a high concordance, both with NS1 immunochromatographic and NS1 ELISA, was observed (95.5\%). Although other authors have reported different sensitivities of NS1 tests for DENV- $3^{16}$, or DENV-2 and DENV$4^{17,24}$, it is noteworthy to mention that during the study period DENV-1 and DENV-3 were the most commonly isolated serotypes $-72.8 \%$ and $23.4 \%$ respectively.

Considering that the procedures were performed according to the strict rules of good laboratory practice and that the presence of the virus in the cell cultures is a definite visible fact, the probability of obtaining false-positive results in virus isolation is remote. In cases in which virus isolation results were negative and NS1 positive, it is necessary to consider at least two possibilities: the limitation of the test employed or that the false-negative results of virus isolation could be due to inadequate transportation and storage of the samples, which can lead to virus inactivation.

For those cases in which the acute samples were NS1 negative, the analysis of the results obtained by IgM-ELISA, with the convalescent samples, showed a concordance of $87.3 \%$ with NS1 ELISA and $95.1 \%$ with the NS1 immunochromatographic test.

Samples from two patients gave inconclusive results on testing with the NS1 immunochromatographic. One sample had an isolated virus and the other one did not. Therefore, it is recommended that NS 1 inconclusive results be confirmed by virus isolation or by IgM-ELISA, with a second sample collected six days after the onset of symptoms.

The Kappa index for the groups I, II and III, showed excellent concordance and reliability (Table 3).

The introduction of NS1 as a tool for screening dengue positive 


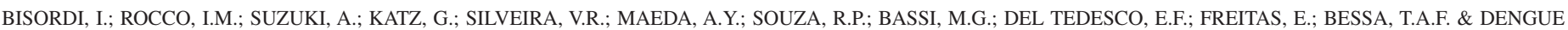
NS-1 GROUP - Evaluation of dengue NS1 antigen detection for diagnosis in public health laboratories, São Paulo State, 2009. Rev. Inst. Med. Trop. São Paulo 53(6): 315-20, 2011.

samples led to an important increased success of virus isolation and also increased the number of counties in the São Paulo State that sent samples for virus isolation and the monitoring of new dengue serotypes (Fig. 1). Furthermore, this strategy can cut costs and reduce the number of samples that are processed by virus isolation.

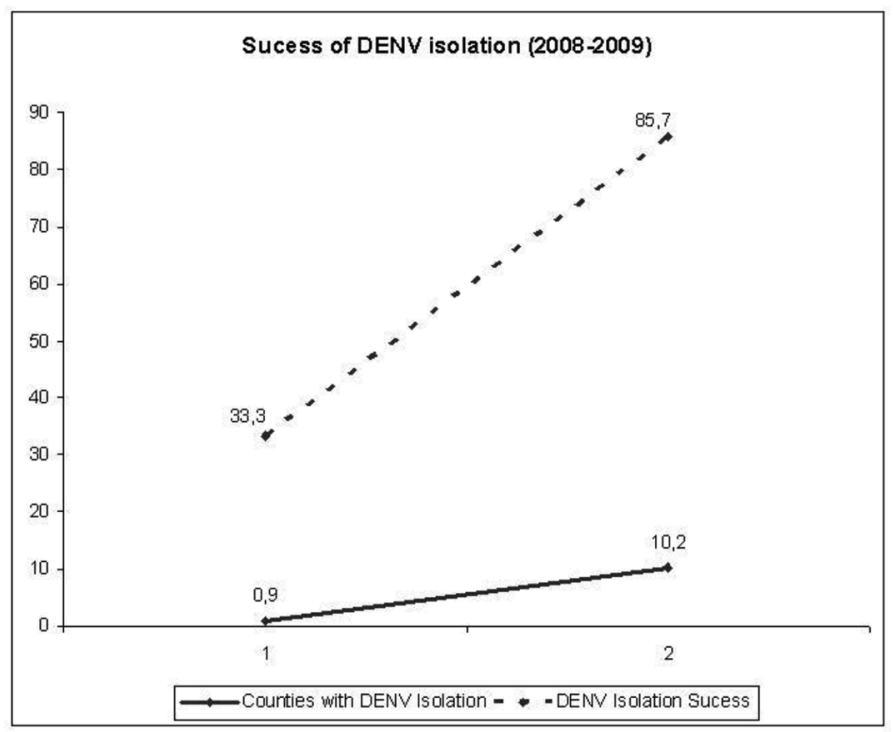

Fig. 1 - Increase of virus isolation and number of counties in São Paulo State that send samples for isolation.

It is very important to plan the introduction of a new methodology into the routine of dengue diagnostics, both in epidemic and inter-epidemic periods. In the study period, 1,439 samples were analyzed only by NS1 detection. Of these, only 68 (4.7\%) were positive, showing that lowering costs and labor by using positive NS1 to screening positive samples for isolation may not be worthwhile without a detailed surveillance plan.

Despite its costs, the analysis for the implementation of the NS1 test for dengue fever in routine diagnoses in Public Health laboratories showed that the NS1 assay, when compared with virus isolation, is reliable. In conclusion, the NS1 assay is highly suitable for samples undergoing screening for virus isolation. In turn, the virus isolation will allow for the monitoring of the DENV-circulating serotypes.

It is important to consider that one methodology should not be employed exclusively to elucidate any given case, but must be used in parallel with other methodologies.

Further studies should focus on whether the NS1 assays are suitable for the diagnosis of fatal cases or patients with severe dengue, dengue hemorrhagic fever, and dengue shock syndrome.

\section{RESUMO}

\section{Avaliação da detecção do antígeno NS1 para diagnóstico de dengue nos Laboratórios de Saúde Pública, Estado de São Paulo, 2009}

Esse estudo avaliou a acurácia do diagnóstico por detecção do antígeno NS1 do vírus Dengue empregando-se ensaios em dois formatos, imunocromatográfico e ELISA, na rotina diagnóstica dos laboratórios de Saúde Pública. Compararam-se os resultados de NS1 com os resultados de isolamento viral e, em parte dos casos, foi feita a comparação com os resultados de IgM-ELISA, obtidos nas segundas amostras. Um total de 2.321 amostras de soros, obtidas no período de março a outubro de 2009, foram analisadas por uma das duas técnicas NS1. As amostras foram divididas em cinco grupos: I, II e III, que incluíram amostras analisadas por testes NS1 e por isolamento de vírus. Os grupos IV e $\mathrm{V}$ incluíram pacientes com a primeira amostra processada por NS1 e segunda por IgM-ELISA. Foram analisadas sensibilidade, especificidade, valor preditivo positivo e negativo, concordância e índice Kappa. Os resultados mostraram que os grupos I, II e III apresentaram alta sensibilidade $(98,0 \%, 99,5 \%$ e 99,3\%), valores preditivos e índice Kappa entre 0,9 - 1,0. Nos grupos IV e V, apenas concordância foi calculada, dado que as amostras foram analisadas quanto à presença de antígeno NS1 ou de anticorpos IgM. Comparando-se os resultados negativos de NS1 com IgM-ELISA houve $92,1 \%$ de concordância. Com base nas constatações feitas, é possível sugerir que a detecção de NS1 pode ser importante ferramenta para monitorar a introdução e disseminação dos sorotipos de Dengue.

\section{ACKNOWLEDGEMENTS}

The authors wish to thank Dr. Marta L. Salomão, Director of Instituto Adolfo Lutz, for her dedication to the development of the present study and Márcia Cristina Toledo Silva from the Núcleo de Cultura de Células, Instituto Adolfo Lutz, for her technical assistance in cell cultures.

\section{REFERENCES}

1. Alcon S, Talarmin A, Dedruyne M, Falconar A, Deubel V, Falmand M. Enzyme-linked immunosorbent assay specific to Dengue virus type 1 nonstructural protein NS1 reveals circulation of the antigen in blood during the acute phase of disease in patients experiencing primary or secundary infections. J Clin Microbiol. 2002;40:376-81.

2. Callahan JD, Wu SJ, Dion-Schultz A, Mangold BE, Peruski LF, Watts DM, et al. Development and evaluation of serotype- and group-specific fluorogenic reverse transcriptase PCR (TaqMan) assays for dengue virus. J Clin Microbiol. 2001;39:411924.

3. Casals J. Immunological technique for animal viruses. In: Moramorosh, K. \& Koprowski, H. Methods in Virology. 3. ed. New York: Academic Press; 1967. p. $175-81$

4. Chambers TJ, Hahn CS, Galler R, Rice CM. Flavivirus genome organization, expression and replication. Annu Rev Microbiol. 1990;44:649-88.

5. Deubel V. The contribution of molecular techniques to the diagnosis of dengue infection. In: Gubler DJ, Kuno G, editors. Dengue and dengue hemorrhagic fever. London: CAB International; 1997. p. 335-66.

6. Dussart P, Labeau B, Lagathu G, Louis P, Nunes MRT, Rodrigues SG, et al. Evaluation of an enzyme immunoassay for detection of dengue virus NS1 antigen in human serum. Clin Diagn Lab Immunol. 2006;13:1185-9.

7. Dussart P, Petit L, Labeau B, Bremand L, Leduc A, Moua D, et al. Evaluation of two new commercial tests for the diagnosis of acute virus infection using NS1 antigen detection in human serum. PLoS Negl Trop Dis. 2008:2:e280.

8. Figueiredo LTM. Dengue in Brazil: present and future perspective. Dengue Bull 2003;27:25-93. 
BISORDI, I.; ROCCO, I.M.; SUZUKI, A.; KATZ, G.; SILVEIRA, V.R.; MAEDA, A.Y.; SOUZA, R.P.; BASSI, M.G.; DEL TEDESCO, E.F.; FREITAS, E.; BESSA, T.A.F. \& DENGUE NS-1 GROUP - Evaluation of dengue NS1 antigen detection for diagnosis in public health laboratories, São Paulo State, 2009. Rev. Inst. Med. Trop. São Paulo 53(6): 315-20, 2011.

9. Fletcher RH, Fletcher SW, Wagner EH. Clinical epidemiology: the essentials. 2. ed. Baltimore: Williams \& Wilkins; 1988.

10. Gubler DJ, Kuno G, Sather GE, Velez M, Oliver A. Mosquito cell culture and specific monoclonal antibodies in surveillance for dengue viruses. Am J Trop Med Hyg. 1984;33:158-65.

11. Guedes MLS, Guedes JS. Bioestatística para profissionais de saúde. Brasília: Ministério da Ciência e Tecnologia/Conselho Nacional de Desenvolvimento Científico e Tecnológico/Ao Livro Técnico; 1988.

12. Koraka P, Burghoorn-Maas CP, Falconar A, Setiati TE, Djamiatun K, Groen J, et al. Detection of immune-complex-dissociated nonstructural-1 antigen in patients with dengue virus infections. J Clin Microbiol. 2003;41:4154-9.

13. Lanciotti RS, Calisher CH, Gubler DJ, Chang GJ, Vorndam AV. Rapid detection and typing of dengue viruses from clinical samples by using reverse transcriptasepolymerase chain reaction. J Clin Microbiol. 1992;30:545-51.

14. Landis JR, Koch GG. An application of hierarchical kappa-type statistics in the assessment of majority agreement among multiple observers. Biometrics. 1977; 33: 363-74.

15. Lee JW, Hall M. Method validation of protein biomarkers in support of drug development or clinical diagnosis/prognosis. J Chromatogr B Analyt Technol. Biomed Life Sci. 2009;877:1259-71.

16. Lima MRQ, Nogueira RMR, Schatzmayr HG, Santos FB. Comparison of three commercially available dengue NS1 antigen capture assays for acute diagnosis of dengue in Brazil. PLoS Negl Trop Dis. 2010;4:e738.

17. McBride WJH. Evaluation of dengue NS1 test kits for the diagnosis of dengue fever. Diagn Microbiol Infect Dis. 2009;64:31-6.

18. Miagostovich MP, Nogueira RMR, Cavalcante SMB, Marzochi KB, Schatzmayr HG. Dengue epidemic in the State of Rio de Janeiro, Brazil: virological and epidemiological aspects. Rev Inst Med Trop Sao Paulo. 1993;35:149-54.

19. Ministério da Saúde/Secretaria de Vigilância em Saúde. Nota Técnica $\mathrm{N}^{\circ} 12$. CGPNCD/DEVEP/SVS/MS. Available from: http://www.portal.saude.gov.br/portal/ arquivos/pdf/nt_para_denv 4_18_01_11.pdf
20. Ministério da Saúde/Secretaria de Vigilância em Saúde MS/SVS. Balanço Dengue. Informe Tecnico. 2011;1:1-12. Available from: http://portal.saude.gov.br/portal/saude/ profissional/area.cfm?id_area $=1525$

21. Nogueira RMR, Miagostovich MP, Schatzmayr HG. Dengue viruses in Brazil. Dengue Bull. 2002;26:77-83.

22. Nogueira RMR, Araújo JM, Schatzmayr HG. Dengue viruses in Brazil, 1986-2006. Rev Panam Salud Publica. 2007;22:358-63.

23. Osanai CH, Travassos da Rosa APA, Tang AT, do Amaral RS, Passos AD, Tauil PL. Surto de dengue em Boa Vista, Roraima. Rev Inst Med Trop Sao Paulo.1983;25:53-4.

24. Ramirez AH, Moros Z, Comach G, Zambrano J, Bravo L, Pinto B, et al. Evaluation of dengue NS1 antigen detection tests with acute sera from patients infected with dengue virus in Venezuela. Diagn Microbiol Infect Dis. 2009;65:247-53

25. Rodriguez-Barraquer I, Cordeiro MT, Braga C, Souza WV, Marques ET, Cumming DA. From re-emergence to hyperendemicity: the natural history of the dengue epidemic in Brazil. PloS Negl Trop Dis. 2011;5:e935.

26. Secretaria de Vigilância em Saúde. Informe Epidemiológico da Dengue. Análise de situação e tendência - 2010. Boletim da semana 09/2010. Ministério da Saúde Available from: http://portal.saude.gov.br/portal/arquivos/pdf/informe_da_dengue_ semana9.pdf. Accessed: 2010, September 2.

27. Shu PY, Yang CF, Kao JF, Su CL, Chang SF, Lin CC, et al. Application of the dengue virus NS1 antigen rapid test for on-site detection of imported dengue cases at Airports. Clin Vaccine Immunol. 2009;16:589-91.

28. World Health Organization. Dengue haemorrhagic fever: diagnosis; treatment and control. Geneva: World Health Organization; 1997.

29. Young PR, Hilditch PA, Bletchly C, Halloran W. An antigen capture enzyme-linked immunosorbent assay reveals high levels of dengue virus protein NS1 in the sera of infected patients. J Clin Microbiol. 2000;38:1053-7.

Received: 27 June 2011

Accepted: 31 October 2011 